Cambridge, in 1675 and took holy orders. In 1682 he was made vicar of Wargrave, Berkshire, but seven years later was appointed to Upminster, where he spent the remainder of his life and where he is buried. Derham united a sincere devotion to his calling with a passion for mathematical and philosophical studies. Elected a fellow of the Royal Society in 1702, he contributed papers to the Philosophical Transactions on the motion of the pendulum in a vacuum, on sound, sunspots, Jupiter's satellites, the aurora borealis and other subjects. His separate writings included his "Physico-theology", 1713; and his "Astro-theology", 1715; while in 1726 he edited "The Philosophical Experiments ... of Robert Hooke and other Virtuosoes". He was made a canon of Windsor, and in 1730 the University of Oxford conferred upon him the degree of D.D. for his services in the cause of religion by his culture of natural philosophy.

\section{Lead Mining in the Northern Pennines}

THe history of lead mining in the Tyne, Wear and Tees areas during the eighteenth and nineteenth centuries was described by Dr. A. Raistrick before the Durham Philosophical Society on March 15. Two companies have worked practically all the mines in these areas, the London Lead Co. and the Beaumonts. The former began with a charter granted in 1692 to a company formed in Bristol to attempt the smelting of ore with coal. This venture closed after two years, but two Quakers, Edward Wright and John Haddon, of London, obtained the reversion of a much older charter (of 1654) of the Society of Mines Royal (Copper), a German concern formed to work Cumbrian ores. Wright seems to have invented the reverberatory furnace, long called the cupola from its shape, and found that it was very suitable for lead refining. They extracted silver, and with some Newcastle Quakers founded a smelt mill at Ryton-on-Tyne in 1704 ; before that (from 1696), difficulties with the oath it contained prevented their taking up the 1692 charter, but these were overcome in 1704, when the accumulated silver was sold to the mint. This company, long known as the "Quaker Lead Company", until 1730 had an output of about $150 \mathrm{oz}$. of silver a week, and in 1705, Sir Isaac Newton then being Master of the Mint, they were granted a mark which appears on most of Queen Anne's coinage until 1737. The maundy money was coined from their silver for another hundred years. They bought ore from Alston Moor, and worked lead also in Flintshire, and finally in Yorkshire, Scotland, Ireland and the Isle of Man. The tale is too long to repeat here, but the Pattinson process of desilverisation was discovered at Blaydon in the Beaumont works. The two concerns worked harmoniously together, and many improvements were made by the London Lead Co. In 1860, the decline set in, the company surrendered all its leases in 1907; and now only three mines are working under the new Weardale Lead Co., and those recently closed will never re-open. An interested visitor at the lecture was the last manager of the old company.

\section{Speed in Aviation}

IN his Friday evening discourse delivered at the Royal Institution on Friday, March 22, Prof. B. Melvill Jones discussed the problems of speed. The speed of aerial transport is limited solely by the power which can be provided to drag the aeroplane through the air, without reference to its support; the power required increases very rapidly with speed, but can be much reduced by good stream-lining. The recent increases in speed of civil air transport are due mainly to improved stream-lining. With well stream-lined aeroplanes the power is expended mainly in overcoming skin friction, so that the detailed study of the skin friction on the curved surfaces of the wings and body merits, and is receiving, great attention by research workers. The magnitude of the skin friction force is delicately dependent on surface smoothness and on the smoothness or otherwise of the flow very close to the surface of the wings and body. After perfect stream-lining, in the ordinary sense, has been achieved, still further important increases in speed would follow from any considerable extension of the area over which the flow remains smooth very near to the surfaces of the wings and body; but to obtain this smooth flow over large surfaces moving at high speeds may be very difficult, and it is still a matter for conjecture how much of the great increase of speed which might conceivably be obtained in this way will ever be realised in practice.

\section{Recent Acquisitions of the Natural History Museum}

THE Department of Entomology has received from Mr. R. W. Lloyd a gift of drawings of quite exceptional interest and value. These consist of the original coloured plates prepared by Jacob Hübner for his "Collection of European Butterflies", pub. lished during the years 1796-1830, at Augsburg in Germany. There are 852 plates in all, a number which exceeds that of the published work by many cancelled and amended copies. Concerning the identity of some of the smaller insects illustrated there has long been doubt; it is hoped the comparisons which it will now be possible to make between the originals of these figures and the material available in this Department will enable most of these doubts to be removed. It is interesting to note that until a few weeks ago it was unknown in Great Britain that these drawings even existed. The Department of Geology has recently acquired from Dr. Wyatt Wingrave a large collection of fossil invertebrates (chiefly Ammonites) from the Lias and Inferior Oolite of the Dorset district. A crystal of gem olivine (peridot) from Burma has been purchased for the Department of Minerals. Presents to the Department include a fine group of large crystals of wolframite from Pelagatos Mountains, Peru, collected by the late Prof. J. W. Gregory and presented by Mrs. Gregory.

THE Department of Botany has received a collection of dried plants made in Twaong (Tibet) and Bhutan by Messrs. G. Sherriff and F. Ludlow. There are 523 flowering plants and 53 cryptogams, which are 
specially dried and preserved, and form a most valuable addition to the herbarium, for few plants have previously been collected from this area. They have not yet been wholly worked over, but it is probable that they contain a percentage of new species which will be of horticultural interest. Seeds of a number of plants likely to prove of horticultural value have been sent and distributed to the more important gardens in the country. The Maharajah of Bhutan kindly granted permission for this expedition to remain longer in the country than originally arranged, and thus enabled collections to be made after the rains were over, which had not been possible in the previous season. Miss Gulielma Lister has presented the 221 original drawings of the "Lister monograph" on Mycetozoa published by the British Museum. The drawings are of considerable artistic beauty and scientific accuracy.

\section{Marine Biology in Ceylon}

Mr. A. H. Malpas, acting marine biologist to the Department of Fisheries, in his Administrative Report (Marine Biology) for the year 1933 (Ceylon, Part 4. Education, Science and Art (G), April 1934, Ceylon Government Press, Colombo) expresses his regret at the severe loss the fisheries research in Ceylon has sustained by the departure on leave, preparatory to retirement, of Dr. Joseph Pearson, who has done so much for the fisheries, especially the fish resources of Ceylon. The survey of the pearl banks in 1933 revealed a promising sign of repopulation of the banks, small branches of oysters being found over most of the paar areas, especially over the West Cheval, usually the first paar to receive spatfall after a long period of barrenness. These oysters are not themselves of any fishable value, but are import. ant as they may produce subsequent spatfalls to repopulate the banks. It is anticipated that a considerable area will be covered with spat at the next inspection. Favourable prospects are also shown for a series of fisheries of the window-pane oyster. Experiments were conducted with the view of ascertaining the effects on pearl oysters of abrupt changes of salinity. It was found that oysters kept in a mixture of 1 part of fresh water to 2 parts of sea water were unaffected after several days, while others kept in a mixture of equal parts of fresh-water and sea-water quickly succumbed. Although the experiments are not conclusive they indicate that, as the pearl banks are some miles distant from land, it is not possible for flood-water to bring about such a reduction in salinity as would be harmful to the pearl oysters.

\section{Survey of Salmon and Freshwater Fisheries}

Problems of biological interest are raised in the Ministry of Agriculture and Fisheries Report on the Salmon and Freshwater Fisheries for the year 1933. In at least three rivers, the Wye, the Severn and the Exe, there have been reports that the size and number of smolt shoals migrating seawards in 1933 were well above the average. It is considered that the great majority of these will have arisen from the 1930 spawning, and that year was noteworthy as one in which the number of fish observed on the spawning beds was unusually low. Under such conditions the eggs will have been relatively undisturbed and well distributed. The possibility arises therefore that the presence of too many fish on the spawning beds may be detrimental by causing disturbance of the already spawned eggs and overcrowding of the newly hatched fry. The production of good broods in years when the breeding stock does not appear to be large has also been observed among some sea fish. A further problem of considerable interest is afforded by the occurrence in 1933 of spring-run salmon in the River Plym, where spring fish are not normally found. Their occurrence follows on the introduction of salmon fry from eggs of early running Scottish fish in 1928. If this is an indication that such fish breed true, always producing spring fish, the results of experiments to eradicate the autumn fish running up after the close season will be watched with interest. Although in the year under review there had been a slight decline in the total catch of salmon and migrating trout, the reported mortality of fish as a result of pollution or from furunculosis has fortunately been low in spite of the dry weather conditions. Much work of interest and value is being conducted at the Alresford Experimental Station from the chemical, botanical and zoological points of view, and the usual surveys of a large number of rivers have been made.

\section{Balance of Life in National Parks}

THE institution of animal reserves, on a large or small scale, eventually raises a question as to whether artificial control of conditions should be encouraged or abolished. Everyone will agree with the dictum that the object is "to preserve National Park areas in as nearly as possible their natural condition and at the same time to make them accessible to the people for study, for recreation, and for play". Dr. Joseph Grinnell quotes with approval, and suggests (in a short article in the Journal of the Society for the Preservation of the Empire, Jan. 1935, p. 6I) that animal life in national parks should simply be left alone. "It can be encouraged in amount and variety most practically by desisting from any avoidable interference with the full range of natural conditions of food and shelter. A do-nothing policy is the soundest policy. . . Also introduction of non-native kinds of animals should be guarded against like the plague." In general, Dr. Grinnell is correct, but the guardian of reserves, especially of those on a small scale, must be on the alert to correct any tendency to extremes in the population. The reason is that no reserve is a thoroughly 'natural area'; it has somewhere a boundary, and at the boundary natural migrations are checked, and unnatural slaughter takes place which rebounds upon the reserve population.

\section{Quality of Wheat}

THE quality of wheat as influenced by environment is the subject of a recent paper by F. T. Shutt and S. N. Hamilton (Emp. J. Exp. Agric., 2, p. 119). The question is not one of scientific interest only, but also of the first commercial importance in the flour. 